九州大学学術情報リポジトリ

Kyushu University Institutional Repository

\title{
The Preservation of Important Rural Japanese Cultural Landscapes : Considering the Warabino Paddy Field as an Example
}

Chiang, Yen-Cheng

Department of Landscape Architecture, National Chiayi University

Weng, Pei-Yi

Department of Horticulture and Landscape Architecture, National Taiwan University

Sato, Noriko

Laboratory of Forest Policy Graduate School of Bioresource and Bioenvironmental Sciences, Faculty of Agriculture, Kyushu University

https://doi.org/10.5109/26182

出版情報：九州大学大学院農学研究院紀要. 58 (1)，pp.209-218，2013-02. Faculty of Agriculture， Kyushu University

バージョン :

権利関係 : 


\title{
The Preservation of Important Rural Japanese Cultural Landscapes - Considering the Warabino Paddy Field as an Example
}

\author{
Yen-Cheng CHIANG ${ }^{1}$, Pei-Yi WENG ${ }^{2 *}$ and Noriko SATO ${ }^{3}$
}

\author{
Laboratory of Forest Policy Graduate School of Bioresource and Bioenvironmental Sciences, \\ Faculty of Agriculture, Kyushu University, Fukuoka 812-8581, Japan \\ (Received October 31, 2012 and accepted November 8, 2012)
}

\begin{abstract}
Since the Law for the Protection of Cultural Properties was amended in 2005 to include "cultural landscapes" in the cultural property protection system, the Japanese government and people have paid attention to the country's cultural landscapes. Currently, Japan has 30 important cultural landscapes, and the benefits brought by these cultural landscapes are extremely valuable to local communities in the context of environmental conservation, economic development, and social education. Therefore, the objective of this study was to explore an extremely significant historical and cultural landscape of Japan. We selected the Warabino paddy field in Ochi, Saga Prefecture, and a site that has been classified as an important cultural landscape, to explore how the protection of the terraced paddy field influences the local biological and ecological conservation, social education, and economy. Besides depending on laws and regulations, the residents' concept of cultural landscape preservation must be continually strengthened. In addition, by promoting terraced paddy field rice production technology, the continuity of traditional arts and workmanship can be ensured while allowing local residents to develop a local identity.
\end{abstract}

Key words: landscape preservation, rural historical landscape, resident participation, mountainous village, tangible cultural property

\section{INTRODUCTION}

\section{The definition and purpose of cultural landscapes}

In 1992, Japan signed the World Heritage Convention and incorporated the concept of world heritage (including cultural landscapes). In 2005, Japan amended this "cultural landscape" concept into its cultural properties protection system. A cultural landscape is defined by Japan's Law for the Protection of Cultural Properties as a landscape area or zone shaped by the daily lives, careers, and unique customs of a population living in a certain region, resulting in the term "cultural landscape." In addition, Kakiuchi (2005) further defined a cultural landscape as the traces of activities left by humans in the natural environment over time and as the cultural phenomena created by humans on the Earth's surface, which is also a type of historical expression method. Therefore, a regional cultural landscape often develops through the accumulation of various cultures over different historical periods and comprises temporality, spatial characteristics, and creativity or creation. Cultural landscapes can be tangible (including cities or towns, settlements, farmlands, roads and paths, churches, monuments, production tools, appliances for daily life, and production technology) and intangible (including language, literature, art, religion, laws, customs, and systems or institutions). Therefore, cultural landscapes can be considered generalized culture. The protection of cultural landscapes

\footnotetext{
1 Department of Landscape Architecture, National Chiayi University, Chiayi 60004, Taiwan (Visiting researcher)

2 Department of Horticulture and Landscape Architecture, National Taiwan University, Taipei 10673, Taiwan

3 Professor, Laboratory of Forest Policy, Faculty of Agriculture, Kyushu University, Fukuoka 812-8581, Japan

* Corresponding author (E-mail: peweng@gmail.com)
}

involves preserving the footprints of human history and enlivening history to allow people to approach and accept history more easily.

\section{The classification and preservation system for cul- tural landscapes}

The classification of cultural landscapes can be considered in relation to international and Japan. Regarding the international classification, cultural landscapes have been listed by international organizations throughout the world as preservation items or within preservation scopes since the 1990s. In 1992, the World Heritage Committee of the United Nations Educational, Scientific, and Cultural Organization (UNESCO) implemented the World Heritage Convention and established relevant operational guidelines to preserve cultural landscapes. According to the guidelines on the inscription of specific types of properties on the World Heritage List of the Operational Guidelines to the World Heritage Convention, the following three categories of cultural landscapes are universally recognized (UNESCO, 2008, p. 86):

1. The most easily identifiable is the clearly defined landscape designed and created intentionally by man. This includes garden and parkland landscapes constructed for aesthetic reasons, which are often (but not always) associated with religious or other monumental buildings and ensembles.

2. The second category is organically evolved landscapes. These result from an initial social, economic, administrative, and/or religious imperative, and their present form is developed by association with and in response to the natural environment. These landscapes reflect the process of evolution in their form and component features, and can be divided into the following two sub-categories: 
(1) A relict (or fossil) landscape is one where the evolutionary process ended at some point in the past, either abruptly or over a period; however, the significant distinguishing features remain visible in material form.

(2) A continuing landscape is one that retains an active role in contemporary society that is closely associated with the traditional way of life, and where the evolutionary process remains in progress. However, it also simultaneously exhibits significant material evidence of its evolution over time.

3. The final category is the associative cultural land-

scape. The inscription of such landscapes on the World Heritage List is justifiable by virtue of the powerful religious, artistic, or cultural associations of the natural element rather than material cultural evidence, which may be insignificant or even absent.

Cultural properties are essential to accurately understand the history and culture of Japan, and they also form the foundations for its future cultural growth and devel- opment. Thus, appropriately preserving and using cultural properties, which are the heritage of Japanese people, is essential (Agency for Cultural Affairs, 2012).

Under the Law for the Protection of Cultural Properties, the national government designates and selects the most important cultural properties and imposes restrictions on activities such as alteration of their existing state, repairs, and export. The national government also implements the diverse measures necessary for preserving and utilizing cultural properties. Measures for tangible cultural properties (such as works of fine art, crafts, buildings, and folk materials) include preservation, disaster protection work, and acquisition. For intangible cultural properties (such as performing arts, craft techniques, manners and customs, and folk performing arts), the measures include subsidies for programs for training successors or for documentation.

In addition, a registration system, which provides more moderate protective measures compared to those of the designation system, has been established for cultural properties (tangible cultural properties, tangible folk cultural properties, and monuments) primarily of the

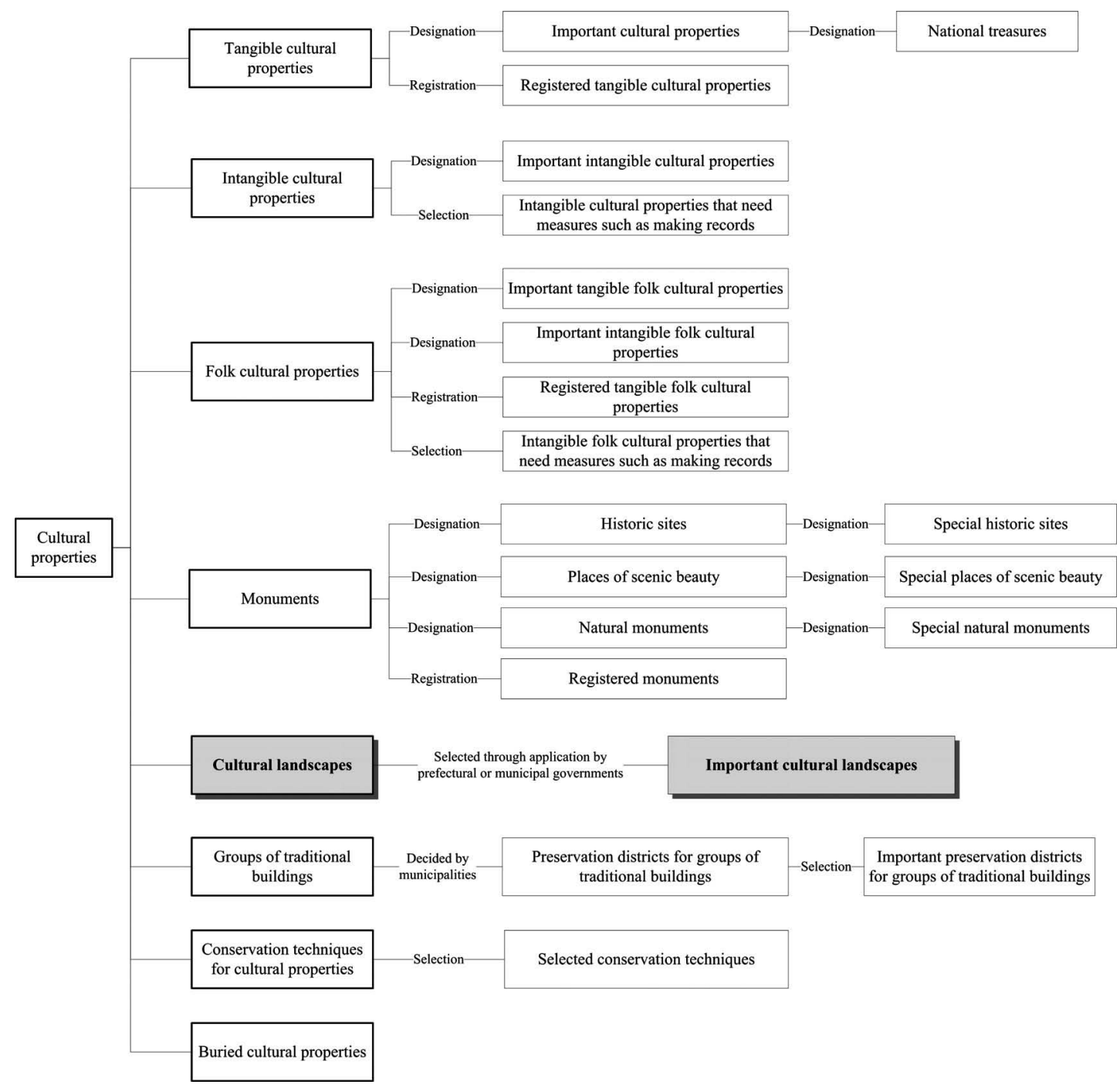

Fig. 1. Schematic diagram of cultural properties.

Source: Division of Monuments and Sites, Department of Cultural Properties (2005) 
Table 1. List of important cultural landscapes

\begin{tabular}{|c|c|c|c|c|c|c|c|c|c|c|}
\hline \multirow{2}{*}{ Name } & \multirow{2}{*}{ Location } & \multirow{2}{*}{ Assigned date } & \multicolumn{8}{|c|}{ Type } \\
\hline & & & 1 & 2 & 3 & 4 & 5 & 6 & 7 & 8 \\
\hline 1. Wetland in Omihachiman & Omihachiman, Shiga Pref. & January 26, 2006 & $\bullet$ & & $\bullet$ & & $\bullet$ & & & $\bullet$ \\
\hline 2. Farm village in the Hondera area, Ichinoseki & Ichinoseki, Iwate Pref. & July 28,2006 & $\bullet$ & & & & & & & $\bullet$ \\
\hline $\begin{array}{l}\text { 3. Cultural landscape along the Sarugawa River devel- } \\
\text { oped from Ainu traditions and modern settlements }\end{array}$ & Biratori Town, Hokkaido & July 26, 2007 & & $\bullet$ & $\bullet$ & & - & & $\bullet$ & $\bullet$ \\
\hline 4. Danbata (terraced fields) in Yusumizugaura & Uwajima, Ehime Pref. & July 26, 2007 & $\bullet$ & & & & & & & \\
\hline 5. Tono Arakawakogen Farm & Tono, Iwate Pref. & March 28, 2008 & & $\bullet$ & & & & & & \\
\hline $\begin{array}{l}\text { 6. Waterfront of Kaizu, Nishihama, and Chinai in } \\
\text { Takashima City }\end{array}$ & Takashima, Shiga Pref. & March 28, 2008 & & & & & $\bullet$ & & $\bullet$ & \\
\hline 7. Ontayaki Village & Hita, Oita Pref. & March 28, 2008 & $\bullet$ & & $\bullet$ & & $\bullet$ & $\bullet$ & & \\
\hline 8. Paddy fields in Warabino & Karatsu, Saga Pref. & July 28, 2008 & $\bullet$ & & & & & & & \\
\hline $\begin{array}{l}\text { 9. Landscape with Tsujun irrigation channel and paddy } \\
\text { fields in Shiraito Plateau }\end{array}$ & Yamato, Kumamoto Pref. & July 28, 2008 & $\bullet$ & & & & $\bullet$ & & $\bullet$ & \\
\hline 10. Cultural landscape in Uji & Uji, Kyoto Pref. & February 12, 2009 & $\bullet$ & & & & $\bullet$ & $\bullet$ & $\bullet$ & $\bullet$ \\
\hline $\begin{array}{l}\text { 11. Cultural landscape in the Shimantogawa River basin: } \\
\text { Villages in the mountains of the headwater region }\end{array}$ & Tsuno, Kochi Pref. & February 12, 2009 & $\bullet$ & & $\bullet$ & & $\bullet$ & & & $\bullet$ \\
\hline $\begin{array}{l}\text { 12. Cultural landscape in the Shimantogawa River basin: } \\
\text { Villages and paddy fields in the mountains of the } \\
\text { upstream region }\end{array}$ & Yusuhara, Kochi Pref. & February 12, 2009 & $\bullet$ & & $\bullet$ & & $\bullet$ & & & \\
\hline $\begin{array}{l}\text { 13. Cultural landscape in the Shimantogawa River basin: } \\
\text { The circulation and traffic among agricultural and } \\
\text { mountainous villages in the upstream region }\end{array}$ & Nakatosa, Kochi Pref. & February 12, 2009 & $\bullet$ & & $\bullet$ & & $\bullet$ & & $\bullet$ & $\bullet$ \\
\hline $\begin{array}{l}\text { 14. Cultural landscape in the Shimantogawa River basin: } \\
\text { The circulation and traffic among agricultural and } \\
\text { mountainous villages it the middle stream region }\end{array}$ & $\begin{array}{l}\text { Shimanto Town, Kochi } \\
\text { Pref. }\end{array}$ & February 12, 2009 & $\bullet$ & & $\bullet$ & & $\bullet$ & & $\bullet$ & $\bullet$ \\
\hline $\begin{array}{l}\text { 15. Cultural landscape in the Shimantogawa River basin: } \\
\text { The vocations, circulation, and traffic in the down- } \\
\text { stream region }\end{array}$ & Shimanto, Kochi Pref. & February 12, 2009 & & & $\bullet$ & $\bullet$ & $\bullet$ & & $\bullet$ & $\bullet$ \\
\hline $\begin{array}{l}\text { 16. Cultural landscape in Kanazawa: The traditions and } \\
\text { culture of the castle town }\end{array}$ & Kanazawa, Ishikawa Pref. & February 22, 2010 & & & & & $\bullet$ & & $\bullet$ & $\bullet$ \\
\hline 17. Paddy fields in Obasute & Chikuma, Nagano Pref. & February 22, 2010 & $\bullet$ & & & & & & & \\
\hline 18. Paddy fields in Kashihara & $\begin{array}{l}\text { Kamikatsu, Tokushima } \\
\text { Pref. }\end{array}$ & February 22, 2010 & $\bullet$ & & & & & & & $\bullet$ \\
\hline 19. Cultural landscape in Hirado Island & Hirado, Nagasaki Pref. & February 22, 2010 & $\bullet$ & & & & $\bullet$ & & & $\bullet$ \\
\hline 20. Waterfront of Harie and Shimofuri in Takashima City & Takashima, Shiga Pref. & August 5, 2010 & & & & & $\bullet$ & & & $\bullet$ \\
\hline 21. Rural landscape of Tashibunosho Osaki & Bungotakada, Oita Pref. & August 5, 2010 & $\bullet$ & & & & & & & $\bullet$ \\
\hline 22. Kure port and fishing townscape & Nakatosa, Kochi Pref. & February 7, 2011 & & & & $\bullet$ & $\bullet$ & & & \\
\hline 23. Cultural landscape of Ojika Island & Ojika, Nagasaki Pref. & February 7, 2011 & & $\bullet$ & & $\bullet$ & & & $\bullet$ & $\bullet$ \\
\hline 24. Fishing village of Sakitsu, Amakusa & Amakusa, Kumamoto Pref. & February 7, 2011 & & & & $\bullet$ & & & $\bullet$ & $\bullet$ \\
\hline 25. Cultural landscape of the Asuka Hinterland & Asuka, Nara Pref. & $\begin{array}{l}\text { September 21, } \\
2011\end{array}$ & $\bullet$ & & & & $\bullet$ & & & $\bullet$ \\
\hline $\begin{array}{l}\text { 26. Fluvial landscape at the confluence of the Tone and } \\
\text { Watarase Rivers }\end{array}$ & Itakura, Gunma Pref. & $\begin{array}{l}\text { September 21, } \\
2011\end{array}$ & $\bullet$ & & & & & & & $\bullet$ \\
\hline $\begin{array}{l}\text { 27. Landscape of the rural villages where gold mining } \\
\text { originated in Nishimikawa, Sado }\end{array}$ & Sado, Niigata Pref. & $\begin{array}{l}\text { September 21, } \\
2011\end{array}$ & $\bullet$ & & & & $\bullet$ & $\bullet$ & & $\bullet$ \\
\hline 28. Cultural landscape of Kuroshima, Sasebo & Sasebo, Nagasaki Pref. & $\begin{array}{l}\text { September 21, } \\
2011\end{array}$ & $\bullet$ & & & & & & & $\bullet$ \\
\hline 29. Cultural landscape of Hisaka Island, Goto & Goto, Nagasaki Pref. & $\begin{array}{l}\text { September 21, } \\
2011\end{array}$ & & & • & & & & & $\bullet$ \\
\hline 30. Cultural landscape of Kitauonome, Shinkamigoto & $\begin{array}{l}\text { Shinkamigoto, Nagasaki } \\
\text { Pref. }\end{array}$ & January 24,2012 & $\bullet$ & & & $\bullet$ & & & & $\bullet$ \\
\hline
\end{tabular}

Source: Web site of the Agency for Cultural Affairs (2012) 
modern period, whose protection is increasingly necessary because of land development and lifestyle changes in recent years. Under the registration system, cultural properties that require special preservation and utilization are registered with the national government. Based on notifications, guidance, and advice, this system aims at to stimulate the voluntary protection of cultural properties by their owners (cultural properties other than those designated by the national or local governments), complementing the designation system (Agency for Cultural Affairs, 2009, 2012).

Moreover, the traditional techniques or skills essential for preserving cultural properties and that require protection are designated as "selected conservation techniques." Protective measures are also implemented for cultural properties buried underground, including certain restrictions on the excavation of buried cultural properties.

The designation, selection, and registration of cultural properties is conducted by the Minister of Education, Culture, Sports, Science, and Technology based on reports submitted by the Council for Cultural Affairs in response to a ministerial inquiry. Figure 1 shows the classifications of various types of cultural property.

According to Japan's domestic classification and the definition of the Law for the Protection of Cultural Properties mentioned previously, a cultural landscape is defined as a landscape area or zone shaped by the daily lives, careers, and unique customs of a population living in a certain region, resulting in the term "cultural landscape." According to the Ministry of Education, Culture, Sports, Science, and Technology Notification No. 47, the following eight types of cultural landscapes exist (Agency for Cultural Affairs, 2008):

1. Farming-related landscape areas, such as rice fields and agricultural lands

2. Wild grazing and pasture landscape areas

3. Timber forests and disaster prevention forests, as well

Prefectures and Cities, Towns, and Villages

Agency for Cultural Affairs

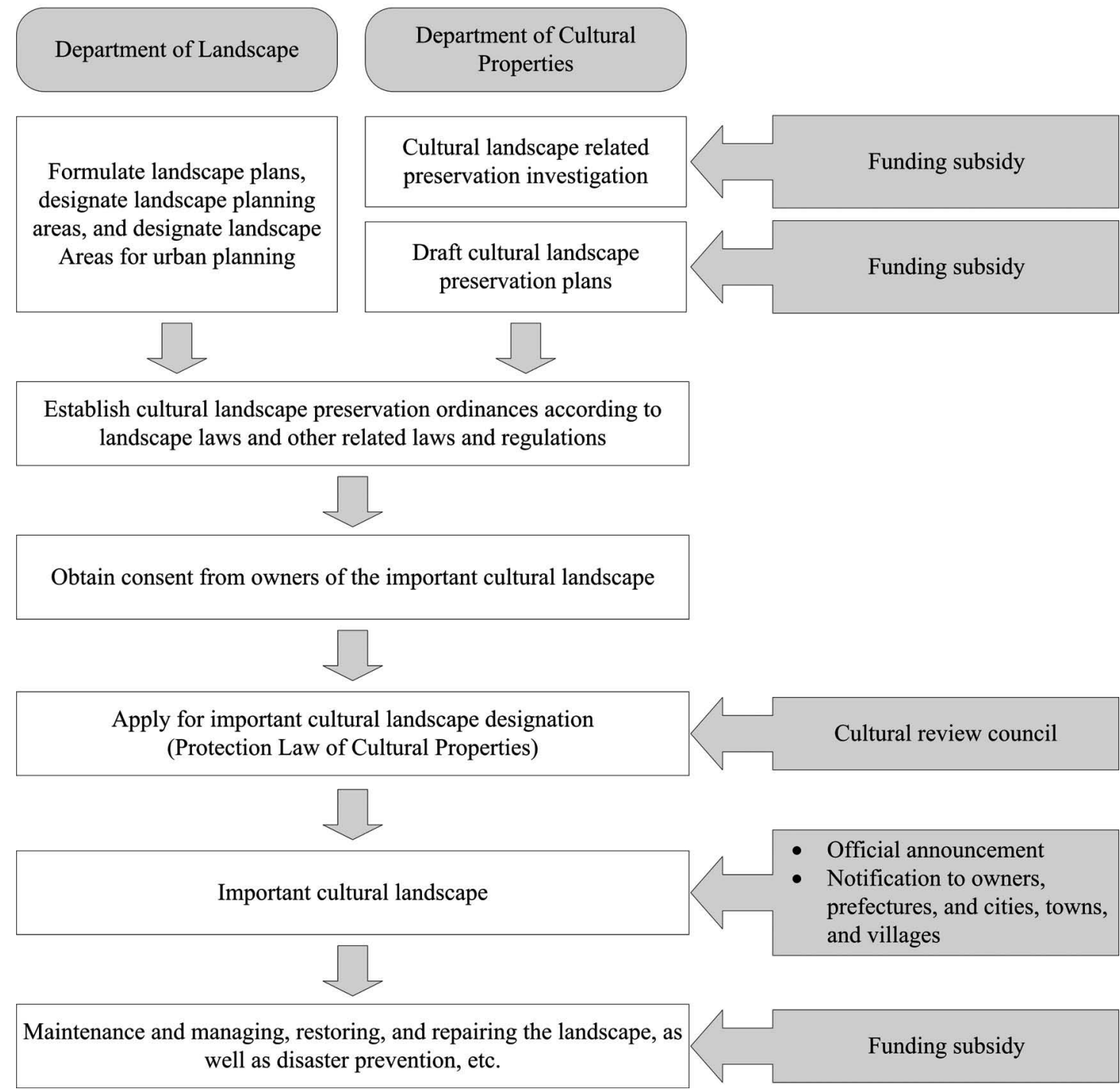

Fig. 2. Cultural landscape preservation system flowchart.

Source: Division of Monuments and Sites, Department of Cultural Properties (2005) 
as other forest use-related landscape areas

4. Aquaculture fisheries and dried vegetable production-related fishery landscape areas

5. Reservoirs, channels, and port-related water use or irrigation facility landscape areas

6. Mines, quarries, and factory group-related mining or production facility landscape areas

7. Roads and distribution-related transportation landscape areas

8. Fenced-off gardens, private woods, and residencerelated landscape areas

Among these eight cultural landscape types, besides the sixth type related to the industrial landscape and the seventh type related to the transportation landscape, the other types clearly emphasize agriculture, forestry, fishery, and animal husbandry landscapes that belong to the organically evolved landscape category specified in World Heritage cultural landscapes. As of January 2012, 30 important cultural landscapes have been registered in Japan (Table 1).

Regarding the preservation system for important cultural landscapes, the entire operation flow or process can be divided as follows: (1) use landscape law to designate landscape planning regions or the cultural landscapes within a landscape area; (2) conduct cultural landscape preservation surveys; (3) enact cultural landscape preservation regulations and ordinances; (4) draft cultural landscape preservation plans; (5) obtain consent from the landowners or managers; and (6) initiate the application and confirm selection. The cultural landscape preservation mechanism process is funded by the Agency for Cultural Affairs (Fig. 2) ( Asano and Lin, 2006). In addition, once a site has been classified and certified by the government as an important cultural landscape (including buildings), the site is entitled to preferential tax mitigation schemes including the reduction of housing taxes by half.

\section{The progression of cultural landscape preservation development}

Before introducing the origins of cultural landscape preservation, we must first discuss the context of cultural property preservation in Japan, which is generally divided into six periods: (1) The emergence of the cultural property protection system; (2) the implementation of national

Table 2. The development process of cultural properties and landscapes

1. The emergence of the cultural property protection system (1868 to 1925)

1871 After the Meiji Restoration period and under the effects of Europeanization and Buddhism or Buddhist temple abolishment ideas, Japan announced the Plan for the Preservation of Ancient Artifacts designed to preserve arts and crafts to secure ancient cultural properties. This was Japan's first cultural property protection mechanism.

1897 After the Sino-Japanese War, national consciousness increased. Against this background, Japan announced the Ancient Temples and Shrines Preservation Act, focusing on the preservation of shrine and temple buildings and their treasures.

1919 The Historical Sites, Places of Scenic Beauty, and Natural Monuments Preservation Law was enacted.

2. Implementation of national treasures protection (1926 to 1945)

1929 Enactment and implementation of the National Treasures Preservation Law.

1933 Law Regarding the Preservation of Important Works of Fine Arts.

3. Enactment and implementation of the Law for the Protection of Cultural Properties (1946 to 1965)

1950 The announcement of the Law for the Protection of Cultural Properties was Japan's first holistic law related to the protection of cultural properties. This law integrated previous cultural property preservation-related laws, such as the National Treasures Preservation Law, Law Regarding the Preservation of Important Works of Fine Arts, and the Historical Sites, Places of Scenic Beauty, and Natural Monuments Preservation Law.

4. Enactment of the Law for the Preservation of Ancient Capitals (1966 to 1975)

1966 With the nation's significant economic growth and urbanization, natural environments and historical environments in large-scale cities throughout the nation were being gradually destroyed. Because the environments of ancient cities or capitals, such as Kyoto, Nara, and Kamakura, which are representative of Japanese culture, were being destroyed, the Law for the Preservation of Ancient Capitals was enacted.

5. Formulation of a system for the preservation districts for groups of traditional buildings (1975 to 1980)

1975 The Law for the Protection of Cultural Properties was amended in 1975, and the Preservation Districts for Groups of Traditional Buildings system was established for historical and cultural preservation.

1978 The Kobe City Landscape Ordinance was developed.

6. Integration of urban and rural regional landscapes (1981 to present)

1992 Signed the Convention Concerning the Protection of the World Cultural and Natural Heritage.

1996 Established the cultural property registry system.

2003 Announced the Policy Outline for Building a Beautiful Nation

2004 Announced the Three Laws on Landscape and Greenery.

2005 An amendment to the Law for the Protection of Cultural Properties was passed and Cultural Landscape Preservation was added to the law.

Source: Amended by Asano and Lin (2006) 
treasures protection; (3) the enactment and implementation of the Law for the Protection of Cultural Properties; (4) the enactment of the Law for the Preservation of Ancient Capitals and protection of historical heritages and relics; (5) the formulation of the system for the preservation districts for groups of traditional buildings; and (6) the integration of urban and rural regional landscapes (Table 2) (Agency for Cultural Affairs, 2005; Lee, 2009).

\section{Study objective}

Based on the previous information, terraced paddy field landscape preservation is an important cultural property in Japan. The benefits provided by these sites are significant and valuable to the local community at the environmental, economical, and social levels. Therefore, the objective of this study was to explore an extremely important historical and cultural landscape of Japan. We selected the Warabino paddy fields of Ochi, Saga Prefecture as an example, to explore how the protection

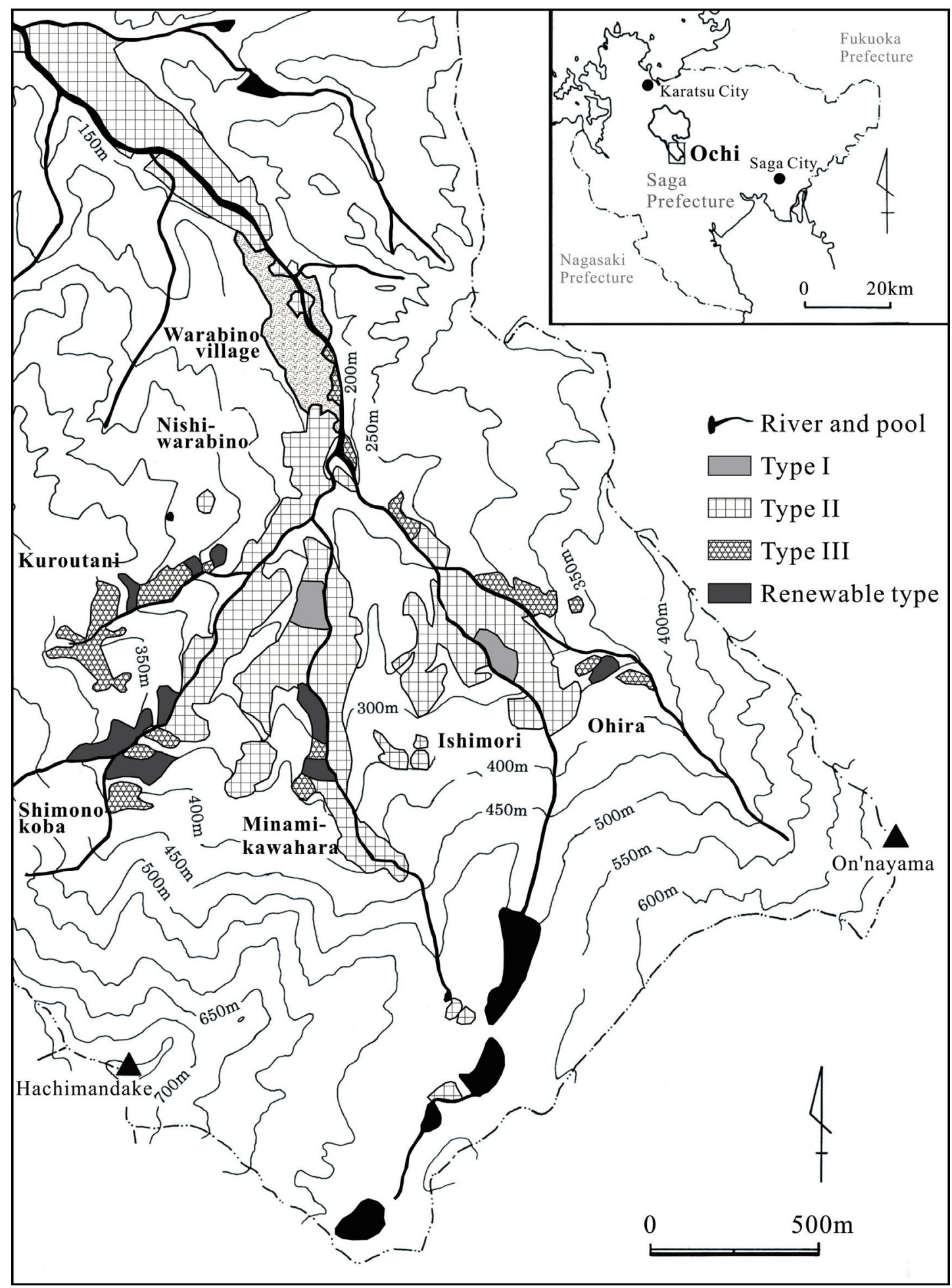

Fig. 3. Site location and terraced paddy field distribution. 
of the terraced paddy field influences the local biological and ecological conservation, social education, and economy.

\section{CASE STUDY}

\section{Case study site description}

The Warabino paddy field is located at the southern tip of Ochi, Karatsu, Saga Prefecture (Fig. 3). The area of the Warabino paddy field is approximately 40 hectares, comprising 1,050 farmlands. Because no residential properties are located upstream of the paddy fields, the area does not have residential wastewater discharge pollution and, thus, produces excellent quality rice. The paddies are distributed 180 to $420 \mathrm{~m}$ above sea level, and are a broad and complete paddy landscape preservation case. Regarding terrain, any paddy cultivation or farming fields with a tilt or incline angle exceeding 1:20 can be classified as a terraced paddy field (Nakashima, 1999). The Warabino paddy field has an average tilt or incline angle of $1: 4$ and is a terraced paddy field with a large height (high-low) gap. Regarding terraced paddy field landscape classification, Japan's terraced paddy fields can nearly all be classified into the following three categories: earth embankment, stone masonry, and mixed types (earth embankment and stone masonry). Our case study site belonged to the stone masonry category. The large terrain gap or difference for Warabino has resulted in the nation's highest stone masonry walls $(8.5 \mathrm{~m})$.

The distribution of the Warabino paddy field extends from the south (upstream) to the north (downstream). The distribution for the area resembles the shape of fingers on a hand, eventually converging at the northern tip where the community settlement is located. Generally, terraced paddy fields can be classified into three type categories and one renewable category (Table 3), and are distributed throughout seven major regions (Table 4).

\section{The course of development}

Japan has many mountains, and mountainous terrain accounts for approximately $76 \%$ of the entire area of the country. Japan has depended on rice planting since ancient times; therefore, numerous terraced paddy field landscapes exist. Terraced paddy fields are defined as rice fields on a sloped terrain. Their unique characteristic is that many small fields are arranged in a staircaselike fashion to form the paddy fields. Terraced paddy field cultivation has existed since between the middle Edo period to the beginning of the Meiji period. In recent years, the Ministry of Agriculture, Forestry, and Fisheries determined that maintaining the existence of terraced paddy fields based solely on their agricultural income was difficult; thus, they selected 100 terraced paddy fields for tourism development. On July 16, 1999, they selected 100 terraced paddy fields in 117 cities, towns, and villages and 134 districts; the Warabino paddy field was among

Table 3. Types of terraced paddy fields

\begin{tabular}{lll}
\hline \multicolumn{1}{c}{ Structural Type } & \multicolumn{1}{c}{ Preservation Concept } \\
\hline Type I & $\begin{array}{l}\text { High stone masonry walls, culverts, } \\
\text { continuous culverts }\end{array}$ & $\begin{array}{l}\text { Maintain status quo: Protects the cultural landscape of the Warabino } \\
\text { paddy field and the wisdom inherited from ancestors and preserves } \\
\text { local ecology, traditional engineering methods, and the landscape. }\end{array}$ \\
Type II & $\begin{array}{l}\text { Maintenance of the rice planting land- } \\
\text { scape }\end{array}$ & $\begin{array}{l}\text { Continues farming while maintaining the beauty of the landscape: } \\
\text { Continues rice farming or planting operations but considers the impact } \\
\text { on the surrounding landscape under the Type I preservation concept. }\end{array}$ \\
Type III & $\begin{array}{l}\text { Areas with more stone masonry ridges } \\
\text { between rice fields }\end{array}$ & $\begin{array}{l}\text { Because of their locations, these districts or areas are committed to } \\
\text { ecological conservation and providing animal or biological habitats. }\end{array}$ \\
Renewable type & $\begin{array}{l}\text { Areas with poor agricultural production } \\
\text { conditions }\end{array}$ & $\begin{array}{l}\text { Considers the feasibility of dry rice planting in the future } \\
\end{array}$
\end{tabular}

Table 4. Area and number of terraced paddy field types

\begin{tabular}{|c|c|c|c|c|c|c|c|c|}
\hline & Ohira & Ishimori & $\begin{array}{l}\text { Minami- } \\
\text { kawahara }\end{array}$ & Shimono-koba & Kuroutani & Nishi-warabino & $\begin{array}{c}\text { Higashi- } \\
\text { warabino }\end{array}$ & Total \\
\hline Type I & $\begin{array}{c}10,211 \\
(9)\end{array}$ & $\begin{array}{c}0 \\
(0)\end{array}$ & $\begin{array}{c}12,500 \\
(9)\end{array}$ & $\begin{array}{c}0 \\
(0)\end{array}$ & $\begin{array}{c}0 \\
(0)\end{array}$ & $\begin{array}{c}0 \\
(0)\end{array}$ & $\begin{array}{c}0 \\
(0)\end{array}$ & $\begin{array}{c}22,711 \\
(18)\end{array}$ \\
\hline Type II & $\begin{array}{c}53,358 \\
(110)\end{array}$ & $\begin{array}{c}42,109 \\
(63)\end{array}$ & $\begin{array}{c}110,346 \\
(212)\end{array}$ & $\begin{array}{c}36,152 \\
(70)\end{array}$ & $\begin{array}{c}0 \\
(0)\end{array}$ & $\begin{array}{c}28,929 \\
(76)\end{array}$ & $\begin{array}{c}0 \\
(0)\end{array}$ & $\begin{array}{c}270,894 \\
(531)\end{array}$ \\
\hline Type III & $\begin{array}{c}21,594 \\
(56)\end{array}$ & $\begin{array}{l}650 \\
(1)\end{array}$ & $\begin{array}{c}5,558 \\
(17)\end{array}$ & $\begin{array}{c}8,431 \\
(13)\end{array}$ & $\begin{array}{c}23,359 \\
(44)\end{array}$ & $\begin{array}{c}3,430 \\
(7)\end{array}$ & $\begin{array}{c}2,212 \\
(4)\end{array}$ & $\begin{array}{c}65,594 \\
(142)\end{array}$ \\
\hline Total & $\begin{array}{c}85,523 \\
(175)\end{array}$ & $\begin{array}{c}42,759 \\
(64)\end{array}$ & $\begin{array}{c}128,404 \\
(238)\end{array}$ & $\begin{array}{c}44,583 \\
(83)\end{array}$ & $\begin{array}{c}23,359 \\
(44)\end{array}$ & $\begin{array}{c}32,359 \\
(83)\end{array}$ & $\begin{array}{c}2,212 \\
(4)\end{array}$ & $\begin{array}{c}359,199 \\
(691)\end{array}$ \\
\hline
\end{tabular}

Note: The numbers in parentheses refer to the number of farmlands. 
those selected (Nakashima, 2004). The selected terraced paddy fields provide experiential activities such as rice seedling transplantation and rice harvesting to allow visitors to experience the traditional mountain rice planting culture.

In 2002, to promote national tourism to the world, Japan organized "Japan's 100 trekking choices," enabling visitors to not only enjoy the local scenery but also obtain an insight into local life through the trail experiences. The Warabino community was one of the 100 areas selected (Nakashima, 2004). In 2003, the Warabino paddy field was awarded the Kyushu Regional Agricultural Administration Office Award from the Ministry of Agriculture, Forestry, and Fisheries. When the Law for the Protection of Cultural Properties was amended in 2005, cultural landscape preservation was included in the amendment to preserve the life customs of traditional settlements, continue traditional cultural arts and workmanship, and maintain the well-preserved cultural landscapes. Subsequently, important national cultural landscape areas were increasingly selected across the country. The Warabino paddy field was classified as an important national cultural landscape on July 28, 2008, becoming Japan's first terraced paddy field designated as an important cultural landscape (Nakashima, 2012).

Older adults in the Warabino community account for approximately $35 \%$ to $40 \%$ of the region's population. During an earlier period, because numerous young people had left the Warabino community to find employment, it was difficult to promote paddy field preservation in the area, which caused a disconnect between generations. Furthermore, because the price of rice and citrus had plummeted at the time, the residents abandoned farming or planted increasing numbers of trees. In 1997, the Saga Prefecture began promoting rural village development. The Warabino community was considered a priority area, which provided opportunities for Warabino paddy field preservation. Subsequently, residents have become dedicated to ecological protection, paddy field engineering method preservation, and the conservation of water quality and surrounding forests to gradually improve the previously negative image of Warabino. In 2001, 36 farming households formed a paddy field rice conservation organization to further promote the Warabino paddy field by cultivating new rice species, developing new brands, and marketing them. In the same year, Warabino farmers won the highest award for the Kyushu rice contest held in Kumamoto, which further popularized the Warabino paddy field rice brand. Because the promotion of rice from the Warabino community inspired numerous urban dwellers to visit this region on holidays and participate in agricultural farming experiences, young people who had left the region for employment gradually returned to the area to engage in agricultural production. Rice from the Warabino community paddy fields is now sold throughout Japan, forming a consensus among local residents that they are proud to have been raised in Warabino. And direct rice sale to consumers by the committee of Warabino is very important point of the certification as important cultural landscape.

\section{Terraced paddy field preservation organizations}

The population of farmers in the Warabino community is approximately 213 , accounting for approximately $95 \%$ of the population. The age of the farmers tends to be older ( $\mathrm{M}=60.5$ years). After the Warabino paddy field became one of 100 terraced paddy fields selected in 1999, a terraced paddy field preservation executive committee was established locally in 2000. This committee included head of Warabino community, members of the Warabino paddy field preservation committee, marketing groups, women's clubs, village or neighborhood representatives, fire corps, and fraternity or fellowship organizations. The committee had a total of 118 patron members and 57 official members. Its main objective was to maintain the preservation, production, and operation of the terraced paddy field cultural landscape. The objective of the Warabino paddy field preservation committee differed from that of the terraced paddy field preservation executive committee. The Warabino paddy field preservation committee focused on controlling the production mechanisms of the Warabino paddy field, for example, reducing the use of pesticides and chemical fertilizers.

\section{The crucial influence of terraced paddy field pres- ervation for the local people \\ Biological conservation}

From the perspective of biological conservation, besides being standing water biological habitats, mountain terraced paddy fields are connected to a series of mountain streams and are within upstream to downstream water corridors that enrich the entire connected wetland ecological system, forming a slow flow resting area for migratory animals (Nakashima, 1999; Takeuchi et al., 2002). The porous structure of terraced paddy fields also increases the habitat space for animals and reduces predation risks. Terraced paddy fields in the mountains have become important ecological compensation or mitigation lands for various stream and forest animals.

\section{Environmental protection}

From the perspective of soil and water conservation, the flat staircase water storage processing method used in terraced paddy field rice farming can delay the arrival of rainfall and peak floods, reduce surface runoff formation, and, thus, prevent soil erosion. The flow of the irrigation waterways or canals and water storage ponds also increases the total area and time of surface water storage. Rainwater slowly filters from the surface to the underground to preserve aquifers or underground water strata in neighboring areas, which benefits the use of water resources and flood prevention (Nakashima, 2012; Takeuchi et al., 2002).

\section{Social education and economics}

Besides the environmental functions described previously, food production and local employment opportunities can enhance the well-being of the social system and cultural assets formed by special landscapes, and are all considered important values of the terraced paddy 
fields. A membership system that includes environmental education experiential activities has also been developed to allow people to participate in farming or field work or directly enter purchase contracts with famers in this historical faming culture. Besides operations of collaborative participation, the public sector has also promoted relevant green subsidies, such as the Mid-Mountain Region Subsidy Policy for the production, ecology, and environmental safety of hilly areas (Surhone, 2009). To ensure the adoption of agricultural production methods in these areas that are environmentally friendly, water conservation, flood storage, ecological integrity, and cultural preservation management regulations are engineered for mountain areas.

The successful promotion of Warabino paddy field rice has been attributed to its preservation committee and its incorporation of marketing concepts into the promotion process. In 2000, the committee promoted the "dream" cultivation plan. This plan included leisure agricultural experiences and the sale of Warabino paddy field rice, which officially went on the market in 2001. At that time, a $5 \mathrm{~kg}$ package of rice was sold for $¥ 2,800$ and was widely popular when introduced. Based on public awareness of ecological protection and sustainable production, and efforts to promote non-toxic agricultural practices, the Warabino paddy field achieved more than 50\% reduction in its use of chemical pesticides and fertilizers, and won the Quality Agricultural Product Certification of Saga Prefecture. The price of Warabino rice then increased to $¥ 3,150$ per 5 kg package, and cultivation area as well as annual production increased steadily. Apart from 2003 and 2005, when annual production declined because of abnormal weather, yearly production has been maintained at an average of 50 metric tons (Table 5), and the Warabino rice brand has became a key source of income for local residents. This success motivated numerous young people to return to their hometown to engage in agricultural production, and they have developed a strong sense of pride in and emotional attachment to the region.

Table 5. Warabino paddy field rice cultivation area and annual production

\begin{tabular}{ccc}
\hline Year & Cultivation Area (ha) & Annual Production (Mt) \\
\hline 2001 & 7.0 & 31.0 \\
2002 & 11.0 & 50.1 \\
2003 & 12.5 & 40.7 \\
2004 & 16.5 & 61.5 \\
2005 & 16.5 & 44.9 \\
2006 & 16.9 & 55.1 \\
2007 & 16.1 & 53.3 \\
2008 & 16.7 & 69.4 \\
2009 & 16.6 & 66.0
\end{tabular}

Source: Karatsu City (2009)

\section{CONCLUSION}

Japan's rice cultivation began in the Yayoi period. With the changing times and increasing urbanization, rice paddies remain one of the original sceneries and representative landscapes of Japan. The historical and cultural legacies, customs, traditional arts and workmanship, and celebration or festival activities left behind by these rice fields were all developed by the rice paddy industries. Before Japan incorporated the cultural landscape amendments into the cultural property protection system in 2005, it had already completed national agriculture, forestry, fishery, and animal husbandry cultural landscape investigations in 2003 (Monuments and Sites Division, Cultural Properties Department, Agency for Cultural Affairs, 2005), and continued to conduct the industrial and transportation based cultural landscape investigations between 2005 and 2008 (Monuments and Sites Division, Cultural Properties Department, Agency for Cultural Affairs, 2008). This demonstrates that cultural landscapes play an important role in national and local development. Although Japan currently has clear laws and regulations for cultural landscapes, the cultural landscape (terraced paddy field) preservation concept must be continually reinforced in local citizens and extended to residents throughout the nation. In addition, terraced paddy field rice production technology should be promoted in the future and an agricultural product certification system should be established for terraced paddy field rice to ensure the continued development of terraced paddy field rice production technology and assure quality. Besides stimulating the economy for local farmers, the revenue generated by rice production can also contribute and be recycled to local ecological conservation

\section{ACKNOWLEDGEMENTS}

This study was supported by research funds of Interchange Association, Japan (IAJ). The authors special thank for Mr. Sasada Keitaro, Ph. D. student of Laboratory of Forest Policy, Faculty of Agriculture, Kyushu University and Mr. Hideki Iwamoto, Mr. Yasuo Doi for their assistance with development of the study procedure.

\section{REFERENCES}

Agency for Cultural Affairs 2005 Japan cultural landscape research: Report on the protection of cultural landscapes that industry related to agriculture. Douseisha, Tokyo

Agency for Cultural Affairs 2008 Study on the protection of cultural landscapes associated with mining, manufacturing, resident livings, and traffics. Douseisha, Tokyo

Agency for Cultural Affairs 2009 Basic concept of protection of cultural property and townscape planning: Cooperation with the Townscape Planning Act. Department of Cultural Properties, Agency for Cultural Affairs, Tokyo

Agency for Cultural Affairs 2012 Cultural Landscapes, Agency for Cultural Affairs. http://www.bunka.go.jp/bunkazai/shoukai/ keikan.html Retrieved August 14, 2012

Agency for Cultural Affairs 2012 Cultural property: A message to 
the future. Department of Cultural Properties, Agency for Cultural Affairs, Tokyo

Asano, S. and M. Y. Lin 2006 The characteristics and prospects of Taiwan's new Cultural Heritage Preservation Act: From historical experience in environmental preservation in Japan. International Conference on Cultural Heritage Administration. January 11-13, 2006, Taipei

Division of Monuments and Sites, Department of Cultural Properties 2005 Attractive scenic in future: Protection system of the cultural landscape. Agency for Cultural Affairs, Tokyo

Kakiuchi, E. 2005 The evaluation of cultural landscape: A case study of world heritage in Gokayama Gassho, Toyama Prefecture. Suiyosha, Tokyo

Karatsu City 2009 Important cultural landscape, Japan's 100 paddy fields: Warabino paddy field. Industry Division, Branch Ouchi, Karatsu
Lee, S. D. 2009 A comparative study of the preservative policy in cultural landscape -Take Japan as an example. Master Thesis, Graduate Institute of Environmental Policy, National Dong Hwa University, Hualien, Taiwan

Nakashima, M. 1999 Japan paddy field conservation. Kokon, Tokyo

Nakashima, M. 2004100 selected trekking of paddy field. Kokon, Tokyo

Nakashima, M. 2012 Paddy field. Kokon, Tokyo

Surhone, L. M., M. T. Timpledon and S. F. Marseken 2009 Paddy field. Betascript Publishers, Beau Bassin, Mauritius

Takeuchi, K., R. D. Brown, I. Washitani, A. Tsunekawa and M. Yokohari 2002 Satoyama: The traditional rural landscape of Japan. Springer, Tokyo

UNESCO 2008 Operational guidelines for the implementation of the world heritage convention. United Nations Educational, Scientific, and Cultural Organization, Paris, France 